Document downloaded from:

http://hdl.handle.net/10251/45545

This paper must be cited as:

Martí Vargas, JR.; Serna Ros, P.; W. M. Hale (2013). Strand bond performance in prestressed concrete accounting for bondslip. Engineering Structures. 51:236-244. doi:10.1016/j.engstruct.2013.01.023.

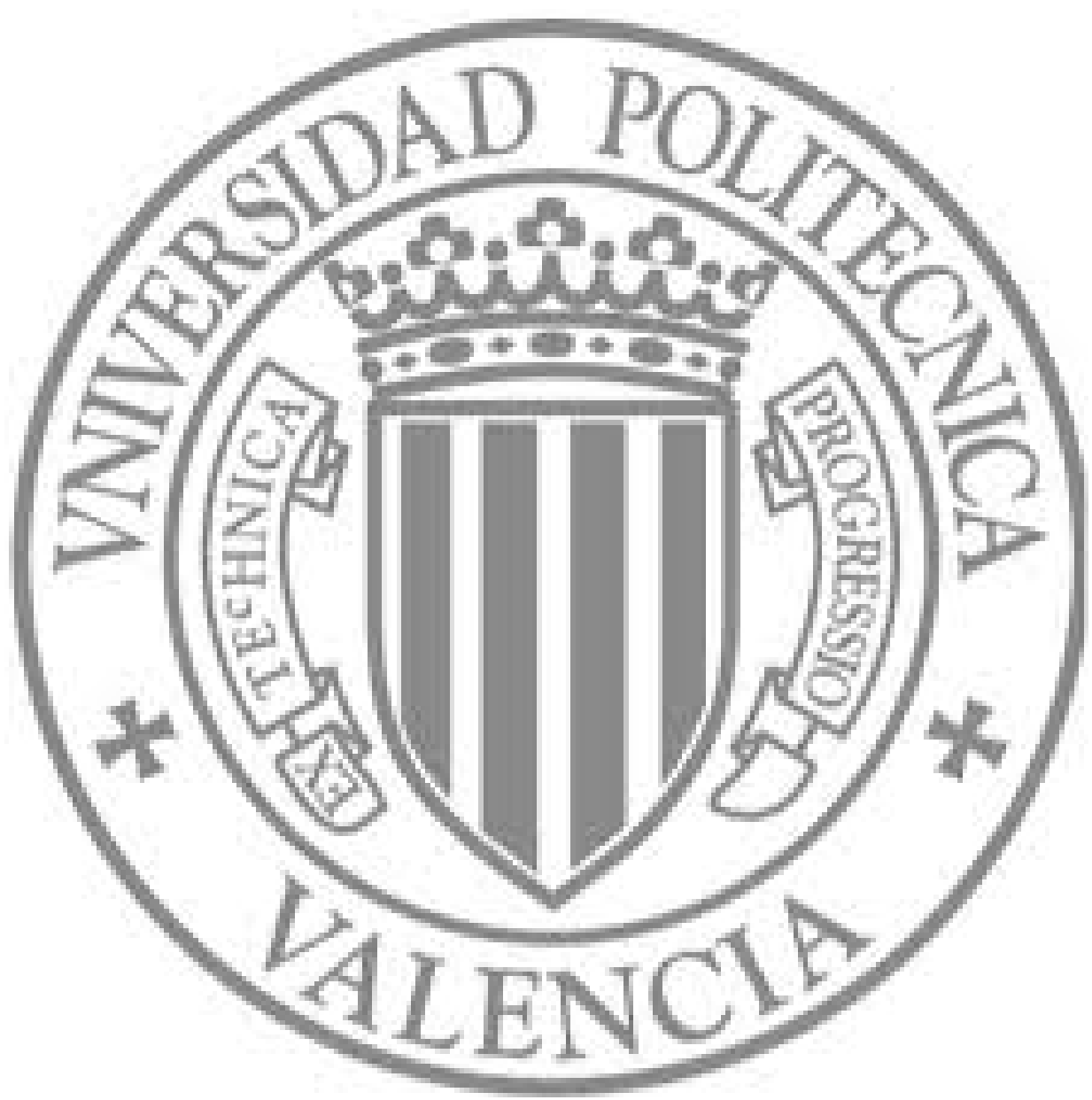

The final publication is available at

http://dx.doi.org/10.1016/j.engstruct.2013.01.023

Copyright Elsevier 


\section{Strand bond performance in prestressed concrete accounting for bond slip}

2

J.R. Martí-Vargas ${ }^{1}$, P. Serna ${ }^{1}$, W.M. Hale ${ }^{2}$

${ }^{1}$ Institute of Concrete Science and Technology (ICITECH), Universitat Politècnica de València, 4G, Camino de Vera s/n, 46022, Valencia, Spain

${ }^{2}$ Department of Civil Engineering, 4190 Bell Engineering Center, 1 University of Arkansas, Fayetteville, AR 72701, United States

e-mail address: jrmarti@,cst.upv.es; pserna@cst.upv.es; micah@uark.edu

*Corresponding author: Tel.: +34 963877007 (ext. 75612); Fax: +34 963877569 ;

e-mail address: jrmarti@cst.upv.es (José R. Martí-Vargas)

\section{Abstract:}

This paper presents the results of an experimental research program addressing the bond behavior of prestressing strands in pretensioned prestressed concrete members after anchorage failure has occurred. A test methodology based on measuring the prestressing strand force and strand end slip at the specimens' free end was employed. Transmission- and anchorage-length tests were performed on several series of prestressed specimens with different embedment lengths using twelve concrete mixes. Average bond stresses along the transmission length and the anchorage length were obtained for specimens with release strengths ranging from 24 $\mathrm{MPa}$ to $55 \mathrm{MPa}$. For the anchorage analysis, a parameter was developed that includes strand slip to be used in determining anchorage length. Based on the test results, an analysis to experimentally substantiate the Stress Waves Theory of Janney has been proposed. Additionally, the potential bond performance of prestressing strands after anchorage failure at the end regions has been suggested.

Keywords: concrete; strand; bond; prestress; failure; anchorage; development; transmission; transfer 


\section{Introduction}

3 Prestressing strands have been widely used in precast pretensioned concrete structures and

4 bridge construction. Sufficient strand bond is necessary in pretensioned prestressed concrete

5 members to guarantee the transfer of prestressing force at release and to assure the ability of

6 strand to develop stress increases when the member is overloaded. An accurate prediction of

7 the lengths affected by the bond stresses in the end regions is necessary to avoid anchorage 8 failures.

These requirements imply the establishment of two lengths: the transmission length and the 11 anchorage length. FIB [1] defines the transmission length (transfer length according to ACI 12 [2]) as the distance along which the prestress is built up in the prestressing strand after prestress transfer. Likewise, FIB [1] defines the anchorage length (development length in [2]) as the embedment length required to transfer the ultimate prestressing strand force to the concrete. Fig. 1 illustrates these lengths and the idealized profile of the prestressing strand 16 stress at the end region of a pretensioned prestressed concrete member. Also shown in Fig. 1 is the complementary bond length [3] (flexural bond length in [2]) defined as distance from the transmission length to the anchorage length. A comparative study on the strand stress values developed along these lengths has been included in [4], and their implications through time have been analyzed in [5].

The necesessary bond mechanisms along these lengths may result in differential 23 displacements (slips) between the prestressing strand and the concrete cross sections [6]. 24 These slips accumulate at the free end of the prestressed member and can be measured (the end slip) and related to the transmission length [7]. 
2 Anchorage length is generally defined and calculated in terms of strand stress. In addition,

3 Buckner [8] indicates that the maximum stress in the prestressing strand must be achieved

4 with a minimum embedment length to prevent strand end slip. However, a limitation or an

5 account for strand slip is not addressed in the main design codes $[2,9,10]$.

6

7 On the other hand, it is generally accepted that strand force in the transmission zone does not vary (and therefore neither the end slips) when the applied loads increase strand force in the complementary bond length (Stress Waves Theory of Janney [11], see Fig. 1). According to this theory, when a pretensioned prestressed concrete member is overloaded, the strand force

11 is at its maximum at the point of maximum moment. This increase of strand force diminishes toward the ends of the member. Strand force increases and then progresses towards the end of the member as a wave, as the magnitude of the moment increases. If this wave reaches the transmission zone, the bond resistance in this zone diminishes due to the reduction in strand diameter that occurs as strand force increases. Anchorage failure can then be expected by 16 general bond slip.

Although it has not been directly verified, the Stress Waves Theory [11] is commonly considered as a hypothesis to determine anchorage length through an iterative flexural testing process. This process involves testing several members by applying concentrated loads at 21 different distances from the member end [12]. With this method, the anchorage length of 22 prestressing strand corresponds to the embedment length when the member achieves its nominal moment capacity and at the same time, the strand slips. An effective anchorage length shorter than the distance between the member end and the loading point has been observed in members with inclined bending cracks [13]. In some prestressed concrete flexural 
1 members, prestressing force may not be fully developed at sections of high moment, and there

2 have been instances in which bond failures have been observed [14]. Moreover, it is 3 suggested that preventing strand slip should be a criterion for design, since increasing strand

4 stress beyond general bond slip has not been investigated experimentally [15]. Therefore, 5 research is needed to understand bond behavior when strand slip continues after an anchorage 6 failure.

7

\section{Objectives}

Experimentally verifying the Stress Waves Theory of Janney [11] and analyzing the bond behavior of prestressing strands after anchorage failure has occurred are the aims of the research program. These purposes require an important condition for testing: the sequential performance of the prestress transfer stage and the anchorage loading stage on a same test specimen. Thus, the anchorage length can be determined on specimens in which the prestress transfer has been previously carried out with the same procedures used in practice of pretensioned prestressed concrete members.

To achieve these objectives, the ECADA test method [16,17], which is based on measuring the strand force, is a viable option. Researchers have suggested defining anchorage length based on two modes [18]: without strand slip at the free end of the member during the loading stage (anchorage length -without slip-, $L_{A}$ ), and accepting strand slip at the free end when a prestressed concrete member is loaded (anchorage length with slip, $L_{A S}$ ).

As part of the research program, prestressed specimens using 12 concrete mixes with compressive strengths at prestress transfer ranging from $24 \mathrm{MPa}$ to $55 \mathrm{MPa}$ were cast. 
1 Transmission and anchorage lengths and examination of bond behavior after anchorage

2 failure was assessed. All specimens contained $13 \mathrm{~mm}$ seven-wire prestressing steel strand.

3

\section{3. Bond mechanisms and models}

5

6 Strand bond behavior depends on several mechanisms developed between the strand surface 7 and the surrounding concrete along the transmission and anchorage lengths: chemical 8 adhesion, friction and mechanical action [1]. The adhesion is destroyed when slip of any 9 magnitude occurs. After slip occurs, the friction mechanism and the mechanical action are activated. Bond stresses are caused by radial compressive stresses around the prestressing strand due to prestress transfer. These radial compressive stresses are the response of the surrounding concrete to the Hoyer effect [19] -strand diameter increase upon transfer of prestress force to member- and to the displacement of the prestressing strand when a slip occurs [6]. However, the increase of prestressing strand stress at loading involves an unfavorable contribution of the Poisson effect by decreasing the strand diameter. This fact reduces the frictional bond mechanism, increasing the importance of the mechanical action $[20,21]$. The mechanical action in prestressing strands is notably different than that in wires (see Fig. 2) because their helical shape allows for a bond stress increase when additional slip occurs.

High bond stresses at transfer can cause bond failures due to the surrounding concrete splitting [12,23]. Bond failures may also result from bursting failures and in spalling failures [1,9]. These failures may cause a complete loss of bond, especially when no confining reinforcement exists [24]. In these cases, the effective prestressing force may be redeveloped by bond at a distance from the damaged location [25]. 
2 High bond stresses at loading may cause anchorage failures by strand slip [26] and concrete 3 splitting [27]. In beams, the increased strand force resulting from equilibrating internal shear

4 forces also increases the force in the strand, most significantly along the transfer length.

$5 \quad$ Failure to account for this action has resulted in both splitting and strand slip failures.

6

7 Strand anchorage failures can lead to an abrupt flexural or shear failure in prestressed

Uniform bond stress distribution along the transmission and the complementary bond lengths has been assumed by several authors and codess [30,31]. This assumption results in bilinear models which imply a linear variation of the prestressing stress as shown in Fig. 1. The slopes of the curves are proportional to the induced bond stresses within each zone.

In contrast with these models and with the Stress Wave Theory [11], the Norsk Standard 3473 [32] and Bruggeling [33] consider it possible that greater bond stresses may develop in the transmission zone when a prestressed concrete member is loaded.

Fig. 3 illustrates the Norsk Standard model [32] for strands gradually released with no transverse reinforcement. According to this model, increases of strand stress by external forces beyond the effective stress involve uniform bond stress increases along the whole of the anchorage length. Consequently, the bond stress along the transmission length increases 
1 approximately $15-30 \%$ over its initial value after prestress transfer (depending on the initial

2 prestress level and prestress losses).

4 On the other hand, Bruggeling [33] establishes the anchorage length directily without a 5 complementary bond length beyond the transmission length. According to Bruggeling [33],

6 the mean bond strength value along the transmission length is proportional to $0.13 f_{c m}\left(f_{c m}\right.$ : 7 mean concrete compressive strength at release) for gradually released strands, and the 8 ultimate bond strength equally distributed over the whole anchorage length is proportional to $90.18 f_{\mathrm{cm}}$. Therefore, a bond strength improvement in the transmission zone from the prestress transfer stage to the anchorage stage is inferred according to a ratio of $1.4(0.18 / 0.13)$.

Requirements regarding trand slip have not been explicitly established in the Norsk Standard provisions [32] or by Bruggeling [33] for the defined lengths.

\section{Bond test method}

In this research program, the ECADA test method was used to investigate strand bond $[16,17]$. This method measures the prestressing strand force during strand release (prestress transfer). Pull-out testing was sequentially performed on the same test specimens. Prestressed concrete specimens with varying embedment lengths were cast to determine both 21 transmission and anchorage lengths.

23 The research program also recommends improvements to the test method. These 24 improvements include measuring strand end slip at the free end of the specimens during 25 loading, and defining two anchorage lengths: anchorage length -without slip- $\left(L_{A}\right)$ and 
1 anchorage length with slip $\left(L_{A S}\right)$. In the first case, the criterion to determine the anchorage

2 length was based on the force achieved immediately before strand end slip occurs. In the 3 second case, only the strand force achieved was considered in determining anchorage length.

\subsection{Test equipment}

7 The specimens were tested in prestressing frames with additional components at both ends as shown in Fig. 4. An AMA (Anchorage-Measurement-Access) system was placed at the pullout end to simulate the sectional rigidity of the specimen during the prestress transfer. This system allowed for increases in strand force during the anchorage loading phase. An adjustable strand anchorage was placed at the transmission end to facilitate strand tensioning and release. To complete the testing program, six prestressing frames and 2 hydraulic actuators were employed.

\subsection{Measurement}

16

17 The ECADA test method requires a force transducer and a pressure sensor to obtain the necessary measurements. The force transducer was located at the end of the AMA system. With the force transducers, strand force was measured during all test phases: tensioning, provisional anchorage, detensioning, and loading. The pressure sensor controlled the force

21 exerted by the hydraulic actuator.

23 A displacement transducer was placed at the free end of the each test specimen (see Fig. 4).

24 This transducer detected free end slip during the anchorage loading and measured strand 
1 movement when slip occurred. Neither of these measurement devices interfered with the

2 strand-concrete bond interface.

\section{4.3. Specimen test procedure}

6 The specimen test procedure included stages for preparation, prestress transfer (release) and 7 anchorage capacity (loading) analysis. Fig. 5 illustrates a test specimen at the loading stage.

8 The different phases for each stage are detailed below.

$9 \quad$ 4.3.1 Test preparation

a) The prestressing strand was placed in the prestressing frame and was anchored at both ends.

b) The hydraulic actuator was positioned at the transmission end of the prestressing

a) The hydraulic actuator was positioned at the transmission end of the prestressing frame to recover the actual prestressing strand force $\left(P_{0}\right)$.

b) The adjustable strand anchorage device was released.

c) The hydraulic actuator was gradually unloaded, and the prestressing force was transferred to the concrete. 
d) The prestressed concrete specimen was supported at the end plate of the prestressing frame included in the AMA system, and the prestressing strand force $\left(P_{T}\right)$ was measured after a stabilization period.

\subsubsection{Anchorage capacity}

a) The hydraulic actuator was positioned at the pull-out end of the prestressing frame.

b) A displacement transducer was placed at the free end of the test specimen.

c) The force in the prestressing strand was gradually increased by loading the hydraulic actuator which separated the strand end anchorage at the AMA system from the prestressing frame.

d) The maximum force achieved during the pull-out operation before strand slip at the free end $\left(P_{A}\right)$ was measured.

e) The maximum force achieved during the pull-out operation $\left(P_{A S}\right)$ was measured.

f) Testing was complete when the prestressing strand fractured, the concrete split, or there was excessive strand slippage.

\subsection{Test analysis of specimen series}

Once the specimens were tested, the transmission and the anchorage lengths were determined by comparing the measured prestressing force to the specimen embedment length. Fig. 6 shows an idealization of the expected curves. Determining the transmission and anchorage lengths required testing 6 to 12 specimens with different embedment lengths at $50 \mathrm{~mm}$ increments.

For the transferred prestressing force values $\left(P_{T}\right)$, the curves are expected to present a bilinear tendency (see Fig. 6), with an ascendent initial branch and a practically horizontal branch 
1 corresponding to the effective prestressing force $\left(P_{E}\right.$, maximum prestressing force value

2 determined by strain compatibility between the prestressing strand and concrete). The

3 transmission length $\left(L_{T}\right)$ corresponds to the shorter specimen embedment length that marks

4 the beginning of the horizontal branch. As shown in Fig. 6, this is the point where $P_{T}=P_{E}$.

6 For the pull-out forces values $\left(P_{A}\right.$ and $\left.P_{A S}\right)$, the curves are expected to present ascendent tendencies (see Fig. 6). A reference force $\left(P_{R}\right)$ was established to analyze the anchorage behavior. The anchorage length $\left(L_{A}\right)$ corresponds to the shorter specimen embedment length of the test specimens in which $P_{R}$ is achieved in the pull-out operation without strand slip at the free end of the specimen, that is, to the first specimen of the series with $P_{A} \geq P_{R}$. The

11 anchorage length with slip $\left(L_{A S}\right)$ corresponds to the shorter embedment length of the test specimens in which $P_{R}$ is achieved in the pull-out operation, that is, to the first specimen of the series with $P_{A S} \geq P_{R}$.

The complementary bond length $\left(L_{C}\right)$ results as the reduction of the transmission length to the 16 anchorage length $\left(L_{C}=L_{A}-L_{T}\right)$.

\section{Experimental program}

An experimental program was developed to verify the Stress Waves Theory [11] and to analyze the bond behavior in prestressed concrete members after anchorage failure has occurred by bond slip. The materials, concrete mixture proportions, and specimens are discussed in detail below.

\subsection{Materials}


2 Specimens were cast using twelve different concretes with water to cementitious material

3 ratios $(\mathrm{w} / \mathrm{cm})$ ranging from 0.30 to 0.50 , cement contents from 350 to $500 \mathrm{~kg} / \mathrm{m}^{3}$, and

4 concrete compressive strengths at strand release $\left(f_{c i}\right)$ from 24 to $55 \mathrm{MPa}$. All concrete

5 mixtures were composed of: cement CEM I 52.5 R [34], crushed limestone aggregate 7-12

$6 \mathrm{~mm}$, washed rolled limestone sand 0-4 $\mathrm{mm}$ and a polycarboxylic ether high range water

7 reducer. All mixtures contained a constant gravel/sand ratio of 1.14. Table 1 summarizes the 8 concrete mixture designs and also includes the tested specimen embedment lengths (see 9 section 4).

11 Low-relaxation, seven-wire steel strand with a $13 \mathrm{~mm}$ nominal diameter and a pitch of 190 $12 \mathrm{~mm}$ was used for all specimens. The strand had a guaranteed ultimate strength $1860 \mathrm{MPa}$ and specified as UNE 36094:97 Y $1860 \mathrm{~S} 7$ 13.0 [35]. The strand manufacturer provided the

14 following information about the strands: diameter of $12.9 \mathrm{~mm}$, section of $99.69 \mathrm{~mm}^{2}$, ultimate 15 strength of $1932 \mathrm{MPa}$, yield stress at $0.2 \%$ of $1780 \mathrm{MPa}$, and modulus of elasticity of 196.70 $16 \mathrm{GPa}$.

\subsection{Specimens and test parameters}

20 The test specimens had a cross section of $100 \times 100 \mathrm{~mm}^{2}$ with a centered single strand. The 21 prestressing strand was used in the as-received condition (free of rust and free of lubricant). 22 For all specimens, the strands were tensioned to $1395 \mathrm{MPa}$, equal to 75 percent of the nominal ultimate strand strength. 
1 All specimens received identical consolidation and curing conditions. The prestress transfer 2 was gradually performed 24 hours after concrete casting. A two hour stabilization period after 3 prestress transfer was allowed before determining the transferred prestressing force $\left(P_{T}\right)$.

5 For the anchorage analysis, a force $P_{R}$ of $158 \mathrm{kN}$ was chosen to represent the force that can be 6 applied to the strand before failure.

In the experimental research, the moment corresponding to a strand slip of $0.1 \mathrm{~mm}$ (first slip) at the free end was used to determine the anchorage length -without slip- $\left(L_{A}\right)$. Previous research has used strand slip values of $0.025 \mathrm{~mm}$ [27] and $2 \mathrm{~mm}$ in [36].

\section{Test results and discussion}

The transmission and anchorage lengths were determined by testing a series of specimens cast with each concrete mixture proportion. Shown in Fig. 7 are the test results for concrete C$16 \quad 350 / 0.50$.

Table 2 summarizes the transmission and anchorage length results and the corresponding prestressing strand forces (ratios in terms of the nominal ultimate strand strength have been included parenthetically) for all concrete mixtures. The effective prestressing force $P_{E}$ is the average value of the strand force in specimens with an embedment length equal to or longer than the corresponding measured transmission length. As shown in Table 2, the $P_{A}$ and $P_{A S}$

23 are slightly greater than $P_{R}$ because of the $50 \mathrm{~mm}$ embedment length increments. As observed, 24 the anchorage length with slip $\left(L_{A S}\right)$ obtained for all concrete mixtures was always shorter 
1 than the anchorage length $\left(L_{A}\right)$, and the anchorage length with slip $\left(L_{A S}\right)$ was less than the 2 transmission length $\left(L_{T}\right)$ for 9 of the 12 cases.

\section{$4 \quad 6.1$ Stress Waves Theory verification}

$6 \quad$ As observed in Fig. 7:

7 a) The prestressing force transferred $\left(P_{T}\right)$ increases as embedment length increases until the

b) From the transmission length $\left(L_{T}=550 \mathrm{~mm}\right.$ in this case) forward, the transferred prestressing force values are essentially constant and independent of the embedment length $\left(P_{T}=P_{E} \cdot\right)$

c) The force achieved at first slip during the pull-out operation $\left(P_{A}\right)$ : i) coincides with the corresponding prestressing force transferred $P_{T}$ when specimen embedment length is shorter than the measured transmission length; ii) is greater than the effective prestressing force $P_{E}$ when specimen embedment length is longer than the measured transmission length, and the obtained $P_{A}$ value increases from $P_{E}$ until $P_{R}$ when the embedment length increases; and iii) for the specimen embedment length equal to the measured transmission length, $P_{A}$ essentially coincides with the effective prestressing force $P_{E}$.

d) The values of maximum strand force achieved during the pull-out operation $\left(P_{A S}\right)$ are greater than the strand force values at first slip $\left(P_{A}\right)$ in specimens with embedment length shorter or equal than the anchorage length $\left(L_{A}\right)$. In specimens where the embedment length was longer than $L_{A}$, the strands frequently ruptured.

24 The aforementioned facts have been observed for all series of specimens tested and they 25 indicate that, after prestress transfer and sequentially the anchorage loading is performed: 
1 a) for cases where embedment length is shorter than the measured transmission length, the

2 increase of the prestressing strand force is only possible if strand end slips occur;

3 b) for cases where embedment length is longer than the measured transmission length, the prestressing strand force can be increased without strand end slip;

c) for cases where the embedment length equals the measured transmission length, the increase in the prestressing strand force from the effective prestressing force causes strand end slips, and $P_{A}=P_{E}$ : the Stress Waves Theory is directly verified by testing a prestressed concrete specimen with embedment length equal to the transmission length, and performing the anchorage loading sequentially after the prestress transfer on the same specimen.

\subsection{Bond performance}

As shown in Fig. 7, when the embedment length equals the transmission length $(550 \mathrm{~mm})$, the strand force achieved during the pull-out operation at first slip $\left(P_{A}\right)$ is slightly greater than the effective prestressing force $P_{E}$. This difference is due to the fact that the resolution in determining the transmission and anchorage lengths depends on the interval $(50 \mathrm{~mm}$ increments) of the specimen lengths tested [37,38]. Also, in the design of the ECADA test equipment [16,17], the strand force measured in the AMA system after release is slightly greater than the effective prestressing force in the specimen. This is because the rigidity of

21 the AMA system is slightly greater than the sectional rigidity of the specimens. Consequently, 22 as shown in Fig. 8, the measured transmission length $\left(L_{T, E C A D A}\right)$ is somewhat longer than the actual transmission length $\left(L_{T, a c t u a l}\right)$. 
1 To account for the difference between measured and actual, an adjusted line to the $P_{A}$ points

2 of specimens with embedment length equal to or longer than $L_{T}$ and shorter than $L_{A}$ (see the

3 idealized upper line in Fig. 7) can be used, as follows (see Fig. 8): a) a new transmission

4 length $\left(L_{T, a d j}\right)$ is determined by extending the adjusted line to the free end to intercept the $P_{E}$

5 value; b) a new anchorage length $\left(L_{A, a d j}\right)$ is determined from the $P_{R}$ value; c) the new

6 complementary bond length $\left(L_{C, a d j}\right)$ is obtained as $L_{C, a d j}=L_{A, a d j}-L_{T, a d j}$. Table 3 summarizes

7 the equations for the adjusted lines and the subsequent corrected values $\left(L_{T, a d j}, L_{A, a d j}\right.$, and

$\left.8 L_{C, a d j}\right)$ for each concrete mixture proportion tested.

9

10 Based on the equilibrium of the prestressing strand force achieved in the different stages and

11 the induced bond stresses that characterize each phenomenon (transmission, anchorage, and

12 anchorage with slip), the average bond stress values are obtained from the following

13 equations:

$14 \quad U_{T}=\frac{P_{E}}{\left(\frac{4}{3} \pi \phi\right) L_{T, a d j}}$

$15 \quad U_{C}=\frac{P_{R}-P_{E}}{\left(\frac{4}{3} \pi \phi\right) L_{C, a d j}}$

$16 \quad U_{A}=\frac{P_{R}}{\left(\frac{4}{3} \pi \phi\right) L_{A, a d j}}$

$17 \quad U_{A S}=\frac{P_{A S}}{\left(\frac{4}{3} \pi \phi\right) L_{A S}}$

18 Where:

$19 U_{T}=$ average bond stress along the transmission length

$20 U_{C} \quad=$ average bond stress along the complementary bond length 
$1 U_{A}=$ average bond stress along the anchorage length

$2 U_{A S}=$ average bond stress along the anchorage length with slip

$3 \quad P_{E} \quad=$ effective prestressing force

$4 \quad P_{R} \quad=$ reference force for the anchorage analysis

$5 \quad P_{A S}=$ maximum strand force anchored during the pull-out operation

$6 \phi \quad=$ nominal diameter of prestressing strand

$7 \quad L_{T, a d j}=$ transmission length (adjusted)

$8 L_{C, a d j}=$ complementary bond length (adjusted)

$9 \quad L_{A, a d j}=$ anchorage length (adjusted)

$10 \quad L_{A S}=$ anchorage length with strand end slip

12 Based on the results for the specimens cast with concrete C-350/0.50, Fig. 9 illustrates the 13 prestressing strand forces for the different adjusted lengths defined in this work. The slopes of 14 the curves correspond to bond forces per unit length and are related to bond stresses around 15 the strand perimeter (see Eq. (1) to (4)). The average bond stress associated with each length 16 is also plotted in Fig. 9.

Table 4 summarizes the average bond stress along each defined length for all concrete 19 mixture proportions. These bond stresses were calculated using Eq. (1) to Eq. (4). Table 4 20 also includes bond stress ratios and their average values. In all cases, $U_{T}$ is greater than $U_{C}$, $21 U_{A}$ has values between $U_{T}$ and $U_{C}$, and $U_{A S}$ is greater than $U_{T}$.

The average $U_{T} / U_{C}$ ratio obtained in this work is 1.9 which is in the order of experimental 24 results reported by other authors. Currently it is considered that beyond the transmission 25 length the bond strength is half the value available within the transmission length [8]. Similar 
1 experimental results are found for beams in [13] $\left(U_{T} / U_{C}=2\right)$ and in [28] $\left(U_{T} / U_{C}=1.4\right)$, and

2 for cylindrical concrete specimens in [39] $\left(U_{T} / U_{C}=2\right)$.

4 The average $U_{A S} / U_{T}$ ratio of 1.3 implies that, in agreement to [32,33], there is a bond strength 5 improvement in the transmission zone from the prestress transfer stage to the anchorage stage.

7 The average $U_{A S} / U_{C}$ ratio of 2.5 implies that a potential bond performance after anchorage 8 failure, by bond slip, is neglected in the traditional bilinear bond models that do not consider 9 strand end slip at the end regions of pretensioned members.

11 Finally, the average $U_{A S} / U_{A}$ ratio of 1.5 proves that the mechanical action exerted by 12 developing strand end slip increases bond strength along $L_{A S}$ (anchorage length with slip) 13 when compared to the bond strength along $L_{A}$ (anchorage length -without slip-). This 14 contribution provides beneficial effects at the end zones of pretensioned members by 15 improving their strength and ductility after anchorage failure occurs. Moreover, as shows Fig. 1610 , it can be observed that the $U_{A S} / U_{A}$ ratio increases when concrete compressive strength 17 increases.

\section{Conclusions}

21 The research program examined the transmission and anchorage length of pretensioned 22 prestressed concrete specimens. The research also analyzed the bond behavior after an anchorage failure by general bond slip. Specimens containing 13-mm seven-wire prestressing

24 steel strand were tested using the ECADA test method. The following conclusions may be 25 drawn from this experimental research: 
1 - For specimens with embedment length shorter or equal to the transmission length, the

2 maximum strand force anchored without strand end slip coincides with the transferred

3 prestressing force.

4 - For specimens with an embedment length longer than the transmission length, the

5 anchored strand force without strand end slip is greater than the transferred prestressing

6 force. This strand force in the anchorage length increases when embedment length

7 increases.

8 - The Stress Waves Theory of Janney has been experimentally verified by testing a

9 pretensioned specimen with an embedment length equal to the transmission length while

10 performing the anchorage loading sequentially after prestress transfer. The maximum

11 strand force anchored without end slip coincides with the effective prestressing force, and

12 increases in strand force during the pull-out stage involve strand end slips.

13 - For all cases, the average bond stress along the transmission length $\left(U_{T}\right)$ is greater than the 14 average bond stress along the complementary bond length $\left(U_{C}\right)$. The obtained $U_{T} / U_{C}$ ratio

15 is 1.9 , which is in accordance with experimental results reported by other authors.

- For all cases, the average bond stress along the anchorage length with slip $\left(U_{A S}\right)$ is greater 17 than the average bond stress along the transmission length $\left(U_{T}\right)$. The obtained $U_{A S} / U_{T}$ ratio 18 is 1.3 , which implies that there is a bond strength improvement in the transmission zone 19 from the prestress transfer stage to the anchorage stage.

20 - The obtained $U_{A S} / U_{C}$ ratio is 2.5 , which implies the existence of a potential bond 21 performance after an anchorage failure by bond slip. Therefore, there is some bonding 22 capacity which is neglected in the traditional bilinear bond models that do not consider 23 strand end slip at the end regions of pretensioned members. 

列

- The obtained $U_{A S} / U_{A}$ ratio is 1.5 , which proves that the mechanical action contribution exerted after anchorage failure by general bond slip enhances bond strength along the anchorage length.

- The $U_{A S} / U_{A}$ ratio increases when concrete compressive strength increases.

\section{Acknowledgments}

The content of the present paper is based on tests which were conducted in the Institute of Concrete Science and Technology (ICITECH), at Universitat Politècnica of València (Spain), in collaboration with the companies PREVALESA and ISOCRON. Funding for this experimental research work was provided by the Spanish Ministry of Education and Science / Science and Innovation and ERDF (Project BIA2006-05521 and Project BIA2009-12722). The authors wish to thank the above companies as well as the concrete structures laboratory technicians at the Universitat Politècnica of València for their cooperation. Finally, the authors also wish to pay their respects to C.A. Arbeláez.

\section{References}

[1] FIB. Bond of reinforcement in concrete. State of the art report. Fib Bulletin $n^{\circ} 10$. Lausanne: International Federation for Structural Concrete; 2000.

[2] ACI Committee 318. Building Code Requirements for Reinforced Concrete (ACI 318-11). Farmington Hills, MI: American Concrete Institute; 2011.

[3] Martí-Vargas JR, Serna P, Navarro-Gregori J, Pallarés L. Bond of $13 \mathrm{~mm}$ prestressing steel strands in pretensioned concrete members. Eng Struct 2012;41:403-412. 
1 [4] Martí-Vargas JR, Hale WM. Predicting strand transfer length in pretensioned concrete:

2 Eurocode versus North American practice, ASCE J Bridge Eng 2012.

3 http://dx.doi.org/10.1061/(ASCE)BE.1943-5592.0000456.

4 [5] Caro LA, Martí-Vargas JR, Serna P. Time-dependent evolution of strand transfer length in 5 pretensioned prestressed concrete members. Mech Time-Depend Mater 2012. 6 http://dx.doi.org/10.1007/s11043-012-9200-2.

7 [6] Uijl JAd. Bond modelling of prestressing strand. In: León R, editors. Bond and 8 development of reinforcement. Farmington Hills, MI: American Concrete Institute; 1998, p. $9 \quad 145-169$.

10 [7] Martí-Vargas JR, Arbeláez CA, Serna-Ros P, Castro-Bugallo C. Reliability of transfer 11 length estimation from strand end slip. ACI Struct J 2007;104(4):487-494.

12 [8] Buckner CD. A review of strand development length for pretensioned concrete members. PCI J 1995;40(2):84-105.

[9] FIB. Model Code 2010. First complete draft - Volume 1. Fib Bulletin nº55. Lausanne: International Federation for Structural Concrete; 2010. [10] CEN. Eurocode 2: Design of concrete structures - Part 1-1: General rules and rules for 17 buildings. European standard EN 1992-1-1:2004:E. Brussels: Comité Européen de 18 Normalisation; 2004.

19 [11] Janney J. Nature of bond in pretensioned prestressed concrete. ACI J 1954;25(9):71720737.

21 [12] Martí-Vargas JR, Arbeláez CA, Serna-Ros P, Fernández-Prada, MA, Miguel-Sosa PF. 22 Transfer and development lengths of concentrically prestressed concrete. PCI J $23 \quad 2006: 51(5): 74-85$.

24 [13] Uijl JAd. Bond of strands in high performance concrete. In: 4th International Symposium 25 on Utilitzation of High-strength/High-performance concrete. París; 1996, p. 1175-1184. 
1 [14] Martin LD, Korkosz WJ. Strength of prestressed concrete members at sections where

2 strands are not fully developed. PCI J 1995;40(5):58-66.

3 [15] Tabatabai H, Dickson Th. The history of the prestressing strand development length 4 equation. PCI J 1993;38(5):64-75.

5 [16] Martí-Vargas JR, Serna-Ros P, Fernández-Prada MA, Miguel-Sosa PF, Arbeláez CA.

6 Test method for determination of the transmission and anchorage lengths in prestressed 7 reinforcement. Mag Concr Res 2006;58(1):21-29.

8 [17] Martí-Vargas JR, Caro LA, Serna P. Experimental technique for measuring the long-term

9 transfer length in prestressed concrete. Strain 2012. http://dx.doi.org/10.1111/str.12019.

10 [18] Martí-Vargas JR, Serna-Ros P, Arbeláez CA, Rigueira-Victor JW. Bond behaviour of 11 self-compacting concrete in transmission and anchorage. Mater Constr 2006;56(284):27-42.

12 [19] Hoyer E, Friedrich E. Beitrag zur frage der haftspannung in eisenbetonbauteilen. Beton 13 und Eisen 1939;38(6):107-110.

14 [20] Hanson N, Kaar P. Flexural bond test of pretensioned prestressed beams. ACI J $15 \quad 1959 ; 30(7): 783-802$.

16 [21] Gustavson R. Experimental studies of the bond response of three-wire strands and some 17 influencing parameters. Mater Struct 2004;37:96-106.

18 [22] Gálvez JC, Benítez JM, Tork B, Casati MJ, Cendón DA. Splitting failure of precast 19 prestressed concrete during the release of the prestressing force. Eng Fail Anal 2009;16:2618202634.

21 [23] Hegger J, Will N, Roggendorf Th, Häusler V. Spannkrafteinleitung und endverankerung 22 bei vorspannung mit sofortigem verbund. Bauingenieur 2010;85:445-454.

23 [24] Uijl JAd. Bond and splitting action of prestressing strand. In: Bond in Concrete: From 24 research to practice. Riga: Riga Technical University and CEB; 1992, p. 2.79-2.88. 
1 [25] Kasan J, Harries KA. Redevelopment of prestressing force in severed prestressed strands.

$2 \quad$ J Bridge Eng 2011;16(3):431-437.

3 [26] Hegger J, Görtz S, Kommer B, Tigger C, Drössler C. Spannbeton-Fertigteilträger aus 4 selbstverdichtendem beton. BFT Helft 2003;8:40-46.

5 [27] Mahmoud ZI, Rizkalla SH, Zaghloul ER. Transfer and development lengths of carbon

6 fiber reinforcement polymers prestressing reinforcing. ACI Struct J 1999;96(4):594-602.

7 [28] Mitchell D, Cook WD, Khan AA, Tham Th. Influence of high strength concrete on 8 transfer and development length of pretensioning strand. PCI J 1993;38(3):52-66.

9 [29] Shahawy M, Cai ChS. Enhancement of the performance of prestressed concrete girders 10 using strand anchorage. PCI J 2001;46(5):82-96.

11 [30] Martí-Vargas JR, Arbeláez CA, Serna-Ros P, Navarro-Gregori J, Pallarés-Rubio L. 12 Analytical model for transfer length prediction of $13 \mathrm{~mm}$ prestressing strand. Struct Eng 13 Mech 2007;26:211-229.

14 [31] Floyd RW, Howland MB, Hale WM. Evaluation of strand bond equations for prestressed 15 members cast with self-consolidating concrete. Eng Struct 2011;33:2879-2887.

16 [32] Norsk Standard. NS 3473: Prosjektering av betongkonstruksjoner, Beregnings-og 17 konstruksjonsregler. Oslo: NSF Gjengivelse uten tillatelse forbudt; 1998.

18 [33] Bruggeling ASG, Huyghe GF. Prefabrication with concrete. The Netherlands: A.A. 19 Balkema/Rotterdam/Brookfield; 1991.

20 [34] CEN. Cement. Part 1: Compositions, specifications and conformity criteria for common 21 cements. European standard EN 197-1:2000. Brussels: Comité Européen de Normalisation; 222000.

[35] AENOR. UNE 36094:1997 Alambres y cordones de acero para armaduras de hormigón pretensado. Madrid: Asociación Española de Normalización y Certificación; 1997. 
1 [36] Khan LF, Dill JC, Reutlinger CG. Transfer and development length of 15-mm strand in

2 high performance concrete girders. J Struct Eng 2002;128(7):913-921.

3 [37] Martí-Vargas JR, Serna P, Navarro-Gregori J, Bonet JL. Effects of concrete composition 4 on transmission length of prestressing strands. Constr Build Mater 2012;27:350-356.

5 [38] Caro LA, Martí-Vargas JR, Serna P. Prestress losses evaluation in prestressed concrete 6 prismatic specimens. Eng Struct 2012. http://dx.doi.org/10.1016/j.engstruct.2012.11.038.

7 [39] Abrishami HH, Mitchell D. Bond characteristics of pretensioned strand. ACI Mater J $8 \quad 1993 ; 90(3): 228-235$. 